\title{
FRANCHISES, REQUIREMENTS CONTRACTS AND TIE-INS: ONE TEST FOR A TANGLED TWO*
}

AlthougH the Supreme Court has often dealt with the antitrust implications of exclusive dealing practices ${ }^{3}$ - requirements contracts, exclusive dealerships and tying arrangements - the Court has failed to develop a unitary rule of law to govern the area. ${ }^{2}$ In recent years, one basic test has emerged to measure the legality of tying arrangements ${ }^{3}$ and a second has been applied to the other forms of exclusive dealing. ${ }^{4}$ Current law thus seems to rest on the assumption that the various exclusive dealing arrangements are clearly distinguishable. ${ }^{5}$ If, however, this assumption is unwarranted, continued application of the two tests in the area may well lead to confusion concerning the applicability of the respective tests to a particular exclusive dealing practice.

Tying arrangements have been defined as agreements by a party to sell one product only on the condition that a buyer also purchase a different, or tied product, from the seller, or that a buyer not purchase the tied product from any other supplier. ${ }^{6}$ The current standard for measuring the validity of such tying arrangements has derived from International Salt Co. v. United States. ${ }^{\top}$ In that case the Supreme Court affirmed a summary judgment holding illegal the lease of patented salt processing machines on the condition that the lessees purchase salt from the lessor. Defendants argued that summary judgment was inappropriate since it precluded trial on the factual issues of whether the re-

*Susser v. Carvel Corp., 332 F.2d 505 (2d Cir. 1964), cert. granted, 33 U.S.L. WEEE 3151 (U.S. Oct. 27, 1964).

1. Among the leading cases in the area of exclusive dealing are: United States $v$. Loew's, Inc., 371 U.S. 38 (1962); Tampa Elec. Co. v. Nashville Coal Co., 365 U.S. 320 (1961); Northern Pac. Ry. v. United States, 356 U.S. 1 (1958); Standard Oil Co. of Cal. v. United States, 337 U.S. 293 (1949); International Salt Co. v. United States, 332 U.S. 392 (1947) ; Fashion Originators' Guild v. FTC, 312 U.S. 457 (1941) ; Pick MIfg. Co. v. General Motors Corp., 299 U.S. 3 (1936); International Business 3fachs. Corp. v. United States, 298 U.S. 131 (1936); FTC v. Sinclair Ref. Co., 261 U.S. 463 (1923); United Shoe Mach. Corp. v. United States, 258 U.S. 451 (1922); Standard Fashion Co. v. Magrane-Houston Co, 258 U.S. 346 (1922).

2. Compare Northern Pac. Ry. v. United States, 356 U.S. 1 (1958), with Tamp3 Elec. Co. v. Nashville Coal Co., 365 U.S. 320 (1961).

3. See, e.g., Northern Pac. Ry. v. United States, 356 U.S. 1 (1958).

4. See, e.g., Tampa Elec. Co. v. Nashville Coal Co. 365 U.S. 320 (1961). For a recent judicial acceptance of the presence of two tests, see Susser v. Carvel Corp., 332 F.2d 505, 511 (2d Cir. 1964).

5. See the approach of the Supreme Court to tying arrangements in Northern Pac. Ry. v. United States, 356 U.S. 1 (1958), the approach of the Court to requirements contracts in Standard Oil Co. of Calif. v. United States, 337 U.S. 293 (1949), and the ease with which the court apparently distinguished various exclusive dealing practices in Susser v. Carvel Corp., 332 F.2d 505 (2d Cir. 1964).

6. See, e.g., Northern Pac. Ry. v. United States, 356 U.S. 1, 5-6 (1958).

7. 332 U.S. 392 (1947). 
straint created by the tying arrangement was unreasunable under section 1 of the Sherman Act or substantially lessened competition under section 3 of the Clayton Act. ${ }^{8}$ In response, the Court held that "it is unreasonable, per se, to foreclose competitors from any substantial market."' Presumably the barc fact that the arrangement prevented competing suppliers from selling $\$ 500,000$ worth of salt in the market closed by the tying arrangement established the requisite substantiality. ${ }^{10}$ Subsequently, confusion developed concerning the application of the per se test of International Salt, ${ }^{11}$ and consequently the Supreme Court redefined the International Salt holding in Northern Pacific Ry. v. United States. ${ }^{12}$ There defendant's sale of land on the condition that the buyer ship all produce from the purchased land over defendant's railroad was attacked under section 1 of the Sherman Act. Answering the contention that monopoly power over the tying item (the land) was necessary to a finding of illegality, the Court held:

They [tie-ins] are unreasonable in and of themselves whenever a party has sufficient economic power with respect to the tying product to appreciably restrain free competition in the market for the tied product and a "not insubstantial" amount of interstate commerce is affected.10

8. Tying arrangements and other forms of exclusive dealing are subject to threo antitrust statutes. Section 1 of the Sherman Act, 26 Stat. 209 (1890), as amended, 15 U.S.C. $\$ 1$ (1958), outlaws every contract in restraint of trade; exclusive dealing contracts clearly fall within its reach. Both a rule of reason and a per se test have been fashioncd under $\S 1$. Exclusive dealing practices are also subject to the broad reach of $\$ 5$ of the Federal Trade Commission Act, 38 Stat. 717 (1914), 15 U.S.C. 41 (1958), which proscribes unfair methods of competition. It has been said that \& 5 comprehends all practices which would violate Sherman Act $\S 1$ and $\S 3$ of the Clayton Act, if not more. FTC v. Motion Picture Advertising Serv. Co., 344 U.S. 392, 394, 400-01 (1953). The only specific statutory enactment aimed directly at exclusive dealing practices is $\S 3$ of the Clayton Act, which provides in relevant part:

It shall be unlawful for any person engaged in commerce . . . to lease or make a sale or contract for sale of goods ... whether patented or unpatented . . . on the condition, agreement, or understanding that the lessee or purchaser thereof shall not use or deal in the goods ... of a competitor or competitors of the lessor or seller, where the effect of such lease, sale, or contract for sale of such condition ... may be to substantially lessen competition or tend to create a monopoly in any line of commerce.

38 Stat. 731 (1914), 15 U.S.C. § 14 (1958). Since $\$ 3$ only reaches exclusive dealing involving commodities, non-commodity cases are brought under either Sherman \& 1 or FTC $\$ 5$.

9. 332 U.S. at 396.

10. The case was decided without reference to the impact of the arrangement in a relevant product or geographic market. The approach of the Court in International Salt was underscored by dicta in Tampa Electric Co. v. Nashville Coal Co., 365 U.S. 320, 326-27 (1961).

11. For a prime example of the Supreme Court's effort to apply the Intcrnational Salt test in a subsequent case, see Times-Picayune Publishing Co. v. United States, 345 U.S. 594 (1953).

12. 356 U.S. 1 (1958).

13. $I d$. at 6 . 
The most recent Supreme Court case involving tying arrangements is United States $v$. Loew's, Inc., ${ }^{14}$ which involved the license of copyrighted feature films on the condition that the licensees accept a package of other films. In Locw's the Court amplified the test of Northern Pacific by holding that sufficient economic power over the tying device is presumed when the tying device is patented or copyrighted, or may be inferred from the uniqueness of, or consumer desirability for, the tying item. ${ }^{15}$ Since uniqueness or desirability might be inferred when a tying arrangement is successful, ${ }^{18}$ and since the "appreciable" restraint of free competition has been measured in quantitative terms rather than by the anticompetitive effect in a carefully defined market, ${ }^{17}$ a tying arrangement which involves a "not insubstantial" amount of commerce would appear illegal without further inquiry. Whether tying arrangements are, in every case, a per se violation of the antitrust laws may still be an open question. ${ }^{18}$ But even if there are special circumstances which justify the use of a tying arrangement, the thrust of current law is undeniably in the direction of per se illegality. ${ }^{10}$

Underlying the case law on tying arrangements is the theory that they generate two kinds of economic injury. First, they are seen as devices which foreclose competing suppliers of the tied product from the buyers' market. $=0$ Foreclosure alone, however, does not seem to have compelled the strict test which has emerged, since there are other kinds of contracts which also foreclose but which are tested under more lenient standards. ${ }^{21}$ The second injury

14. 371 U.S. 38 (1962).

15. Id. at $45-46$.

16. If a tying arrangement is accepted, on standard theory it would be the buyer's desire to acquire the tying product which prompted the buyer to accept. Uniqueness or desirability, therefore, would be the core reason for the success of such an arrangement.

17. See, e.g., International Salt Co. v. United States, 332 U.S. 392 (1947).

18. For a discussion of the per se concept as applied to tying arrangements, see Baldwin \& McFarland, Tying Arrangenents in Law and Economics, 8 Arrmtrost Bunc. 743 (1963). For judicial comment on the possibility that the per se rule is not appliable in - every case, see Standard Oil Co. of Calif. จ. United States, 337 U.S. 293 at 305 (1949). See also White Motor Co. v. United States, 372 U.S. 353, 263 (1963); Brown Shoe Co. v. United States, 370 U.S. 294, 330 (1962). For cases actually upholding tying arrangements, see Baker v. Simmons Co., 307 F.2d 458 (1st Cir. 1962); Dehydrating Process Co. v. A. O. Smith Corp., 292 F.2d 653 (1st Cir.), cert. denied, 363 U.S. 931 (1951); United States v: Jerrold Electronics Corp.. 187 F. Supp. 545 (E.D. Pa. 1960), affd per curiam, 365 U.S. 567 (1961). For an analysis of the kind of tying arrangement contemplated by the dicta in White Motor and before the court in Jerrold Elcclronics, see Note, The Use of Tie-Ins in New Industries, 70 Yale L.J. 804 (1961).

19. For a careful study of the law concerning tying arrangements, and an argument supporting a rule of per se illegality, see Turner, The Validity of Tying Arrangements Under the Antitrust Lazes, 72 HARv. L. Rev. 50 (1958).

20. See, e.g., United States v. Loew's, Inc, 371 U.S. 38, 45 (1962).

21. For example, see the Supreme Court's treatment of requirements contracts in Standard Oil Co. of Calif. v. United States, 337 U.S. 293 (1949), which at least required the testing of effect in a relevant geographic and product market, and the more recent and less strict approach in Tampa Elec. Co. v. Nashville Coal Co., 365 U.S. 320 (1961). 
is thought to be the forcing of buyers to forego their choice of stubstitutes for the tied products. ${ }^{22}$ Both injuries ultimately result from the leverage the seller has over the tying device, without which there would be no inducement to purchase the tied product. Tying arrangements have been characterized as monopolizing devices which allow a seller to transfer his economic power from one market to another; illegality is premised on the application of leverage to exploit a second market, where, absent a tying arrangement, the tied product would have to compete on its merits. ${ }^{23}$

Concurrent with the development of tie-in case law a second doctrine con" cerning other forms of exclusive dealing has appeared, and has recently culminated in a test which is significantly different from that applicable to tying arrangements. This body of law has its roots in Standard Oil Co. of California v. United States (Standard Stations). ${ }^{24}$ In that case the Supreme Court held illegal Standard's requirements contracts with $16 \%$ of the independent gasoline stations in the relevant geographic market. ${ }^{25}$ Justice Frankfurter, writing for

22. See, e.g., Northern Pac. Ry. v. United States, 356 U.S. 1, 6 (1958).

23. For a case which explains clearly the Supreme Court's reaction to situations involving transfers of power, see United States v. Griffith, 334 U.S. 100 (1948). In TimesPicayune Publishing Co. v. United States, 345 U.S. 594 (1953), the Supremc Court ex:plained the leverage theory:

[T] he essence of illegality in tying agrecments is the wielding of monopolistic leverage; a seller exploits his dominant position in one market to expand his cmpire into the next.

345 U.S. at 611. In the same vein, the Supreme Court had earlier stated:

[O]nly the prospect of reducing competition would persunde a seller to adlant

[a tie-in] . . a and only his control of the supply of the tying device, whether conl-

ferred by patent monopoly or otherwise obtained, could induce a buyer to enter onc. Standard Oil Co. of Calif. v. United States, 337 U.S. 293, 306 (1949). The Attorncy General's report on antitrust laws also adopts this view of tying arrangements. Reroutr of the Atr'y Gen.'s Nat'l Comm. to Study the Antitrust Laws 145 (1955). For a comprehensive view of tying arrangements which weaves together the strands of these opinions, see Turner, supra note 19.

Whether such leverage is exercised with monopolistic intent in every case has been seriously questioned: See Bowman, Tying Arrangements and the Leverage Problem, 67 YALE L.J. 19 (1957); Baldwin \& McFarland, supra note 18. Director \& Levi, Lave and the Future: Trade Regulation, 51 Nw. U.L. Rev. 281, $291-92$ (1956).

24. 337 U.S. 293 (1949).

25. Id. at 295. The contracts involved roughly $\$ 57,000,000$ of gasoline, Standard's own stations accounted for $6.8 \%$ of total sales, and those under requirements contracts added another $6.7 \%$; even taken together, the percentages did not give Standard a dominant position in the market. In addition, there was said to be a trend in the industry towards vertical integration at the dealer level. Whether the case turned on a single figure or a conglomeration is debatable. For Justice Frankfurter's own view of his opinion in Standard Stations, see FTC v. Motion Picture Advertising Serv. Co., 344 U.S. 392, 401 (1953). The case is extensively analyzed in Kessler \& Stern, Compctition, Contract and Vertical Integration, 69 YALE L.J. 1 (1959). For the varying and vehement responses from the academy to Standard Stations, see the sources collected in Bok, The Tampa Electric Case and the Problem of Exchisive Arrangements under the Clayton Act, 1961 Supreme CT. Rev. 267, 275 n.28. 
the majority, stated that requirements contracts, unlike tying arrangements, may offer economic advantages to buyers and sellers, ${ }^{20}$ and he suggested that varying standards might be established to determine the effect on competition of the two practices. ${ }^{27}$ Justice Frankfurter, however, rejected the possibility of establishing a test measuring the economic usefulness of exclusive dealing practices on the ground that the economic inquiry necessitated by such a test would be "ill-suited for ascertainment by courts." parently adopted a test for requirements contracts which did not consider the economic benefits of the arrangements but rather drew the line of illegality at quantitative substantiality ; a violation of the anti-trust laws presumably was proved by the fact that competition had been foreclosed in a "substantial" share of the line of commerce affected.29

Subsequently, the Court reassessed the test of Standard Stations in Tampa Electric Co. v. Nashville Coal Co., ${ }^{\mathrm{s} 0}$ which involved a private antitrust attack against a twenty-year requirements contract for the supply of coal, foreclosing $.77 \%$ of the relevant market. ${ }^{31}$ Rather than deciding that the slight degree of foreclosure in Tampa Electric removed the case from the Standard Stations test, the Supreme Court instead took this opportunity to reexamine the antitrust implications of requirements contracts ${ }^{32}$ and, presumably, exclusive dealerships. ${ }^{33}$ The Court implied that the economic purposes of requirements contracts should be given consideration, ${ }^{34}$ and held that the anticompetitive effect of the practice must be assessed in the relevant geographic and product markets. ${ }^{35}$ Further, the Court stated that a mere showing of dollar amount substantially by itself will fail to establish illegality. ${ }^{38}$ Although the Tampa Electric test may not replace completely that of Standard Stations, ${ }^{37}$ it certainly encour-

26. 337 U.S. at 306-07.

27. Id. at 307-08.

28. Id. at 310.

29. Id. at $298,314$.

30. 365 U.S. 320 (1961).

31. Id. at 333.

32. Id. at 327.

33. The theory that exclusive dealerships and requirements contracts should be tested under the same standards was accepted in Susser v. Carvel Corp., 332 F.2d 505, 516 (2d Cir. 1964). It would not seem that exclusive dealerships deserve a per se test; in fact, such practices received a form of blessing in Justice Brennan's concurring opinion in White Motor Co. v. United States, 372 U.S. 253, 270-71 n.11 (1963).

34. 365 U.S. 320, 334 (1961).

35. Id. at $327-29$.

36. Id. at 334 .

37. The court in Susser v. Carvel Corp., 332 F.2d 505, 516 (2d Cir. 1964), thought that Tampa Electric deviates from "the more rigorous and inflexible rule" of Slandard Stations, and implied that the Standard Stations test is a thing of the past. However, there is language in Tampa Electric which suggests that the Standard Stations test is still applicable in certain situations. See 365 U.S. 320, 334 (1961). This view of the Tampa Electric case is supported in dicta in Brown Shoe Co. v. United States, 370 U.S. 294, 330-31 (1962). 
ages the kind of economic inquiry which Standard Stations rejected, and which Northern Pacific disallows in cases involving tying arrangements. While the precise details of the Tampa Electric test remain unclear, at the least it establishes a more lenient standard than that applicable to tying arrangements. ${ }^{88}$

When a court is presented with an exclusive dealing practice, the focus of inquiry and perhaps the outcome will depend upon which of the two current tests for exclusive dealing is applied. It is, then, of cardinal importance for courts to distinguish between the practices in selecting the proper test. This assumes, as does the current law, that various exclusive dealing practices are readily distinguishable. Indeed, the opinions in Susser $v$. Carvel Corp., ${ }^{80}$ a recent Second Circuit case involving exclusive dealing arrangements, rested upon this assumption. Analysis of the case, however, calls this crucial asstumption into question, and reveals that various exclusive dealing arrangements may, in many situations, be indistinguishable.

In Carvel, nine Carvel franchisees attacked the Carvel franchise contract in a treble damage antitrust action, and alleged that the franchise embodied threc illegal exclusive dealing practices : tying arrangements, ${ }^{40}$ exclusive dealerships, ${ }^{41}$ and requirements contracts. ${ }^{42}$ Plaintiffs argued that they were forced to purchase from Carvel or Carvel-approved sources the elements of the Carvel end product - mix, cones, toppings, and flavorings - in order to acquire certain equipment from Carvel. Plaintiffs characterized this provision of the contract as a tying arrangement. ${ }^{43}$ The obligation in the Carvel franchise which requires

38. This interpretation of Tampa Electric reccives clear support in Susscr v. Carvel Corp., 332 F.2d 505 (2d Cir. 1964). For an excellent and exhaustive analysis of the Tampa Electric case, see Bok, supra note 25. Professor Bok considers Tampa Elcctric to have moved away from the "uncompromising prohibition of Standard Stations," Id. at 283, notwithstanding the fact that the factors relevant to the Tampa Electric test are vague. Although Tampa Electric encourages a rational inquiry into relevant factors, a subsequent case, Mytinger \& Casselberry, Inc. v. FTC, 301 F.2d 534 (D.C. Cir, 1962), scems to havo read Tampa Electric to apply only in de minimis foreclosure situations. Id. at 39. Prior to the Supreme Court decision in United States v. Loew's, Inc. 371 U.S. 38 (1962), somo commentators expressed forlorn hope that the Court's approach in Tampa Elcctric would be extended to the law of tying arrangements. See Baldwin \& McFarland, supra note 18.

39. 332 F.2d 505 (2d Cir. 1964), cert. granted, 33 U.S.L. WEEK 3151 (U.S. Oct. 27, 1964). On different facts, Carvel's arrangements were attacked under $\$ 5$ of the Federal Trade Commission Act. Carvel Corp., 3 Trade Reg. Rep. (1964 Trade Cas.) If 16,921 (June 4, 1964). The examiner, on the reasoning of Judge Lumbard's dissent in Susser v. Carvel Corp., found only Carvel's alleged tying arrangement illegal under $\$ 5$.

40. Dealer's Franchise Agreement, Appendix Brief for Appellec, pp. 85c, 89c-90c, Susser v. Carvel Corp., 332 F.2d 505 (2d Cir. 1964).

41. Id. at $89 \mathrm{c}$.

42. The requirements contracts ran between Carvel and the independent supplicrs of end product elements. For examples, see Appendix Brief for Appellee, pp. 139c, 154c, Susser v. Carvel Corp., 332 F.2d 505 (2d Cir. 1964).

43. At trial before the district court, Susser v. Carvel Corp., 206 F. Supp. 636, 614 n.7 (S.D.N.Y. 1962), Judge Dawson, finding for defendants on all the allegations, recornized that the right to use the trademark was the focus of the arrangement. Since plaintiffs did not argue that characterization of the tying device, he based his opinion on tho 
the dealers to sell only Carvel or Carvel-approved products was challenged as an invalid exclusive dealership. And the requirements contracts between Carvel and the suppliers of the elements of the end product were attacked as refusals to deal which prevented the franchisees from purchasing elements directly from the suppliers. ${ }^{44}$ Plaintiffs stipulated in a pre-trial order that they were relying solely on per se violations of the antitrust laws, and would introduce as evidence only the franchise and supplier contracts. ${ }^{10}$

Both the majority of the court and Judge Lumbard in dissent agreed that there was a tying arrangement, but found that the right to use Carvel's trademark, not various items of equipment, was the tying device and that the end product elements, which had to be purchased from Carvel or from Carvelapproved sources, were the tied products. The majority, however, found that Carvel's trademark did not generate sufficient economic power to bring the tying arrangement within the scope of the northern Pacific test. ${ }^{40}$ This finding was grounded on the majority's belief that the current test requires a factual inquiry into the market power created by the tying device, and that the requisite power cannot be presumed from the fact that the tying device involved a statutorily conferred monopoly. ${ }^{47}$ This reading of Northern Pacific, however, incorrectly emphasizes the importance of the role of the tying device; such a factual investigation, in effect, removes much of the per se thrust of the test. In addition, the majority's formulation of the test discounts the Supreme Court's holding in Loew's that sufficient power is to be presumed from tying devices involving copyrights, patents and, inferentially, trademarks. Disagreeing with the majority, Judge Lumbard accepted the presumption of power doctrine of Loew's and reasoned that trademarks satisfy the presumption. ${ }^{48}$ Since Judge Lumbard also found that the tied products involved a not insubstantial amount of commerce, he considered the tying arrangement illegal..$^{10}$

On a definitional level, however, Carvel's alleged tying arrangement can be analyzed as a requirements contract, rather than a tie-in. A probable object of the arrangement was to provide a guaranteed source of end product elements to the franchisees at stabilized prices - the goal usually attributed to requirements contracts. ${ }^{50}$ If the franchisees pooled their purchasing power and entered

dispensing freezers as the tying articles, and found the tie-in legal on the ground that it was necessary to protect Carvel's trademark. On appeal, plaintiffs seem to have continued the argument that the tying device consisted of machinery.

44. The case also involved a price fixing allegation which is not hercin discussed.

45. The circuit court was in disagreement as to the effect of the stipulation. Judge Lumbard saw the pre-trial order as only limiting the evidence, 332 F.2d at 512-13, while the majority of the court was concerned with the substantive aspect of the stipulation, 332 F.2d at 518.

46. 332 F.2d at 519 .

47. Id. at $519-21$.

48. Id. at 513 .

49. Id. at 514-15.

50. Judge Lumbard would apparently admit this to be at least one goal of the arrangement. Id. at 514. 
into such contracts with suppliers, the arrangement clearly would be a requirements contract. And even if the franchisees requested Carvel to negotiate for them with suppliers, the arrangement still could be defined as a requirements contract. However, since Carvel took the initiative in contracting and stipulated that the franchisees must accept their requirements from Carvel-selected sources, that which definitionally might have been a requirements contract becomes subject to characterization as a tying arrangement. But the possibility of labeling Carvel's alleged tie-in a requirements contract cannot be discarded lightly, since in two cases involving similar circumstances, the requirements contract characterization has prevailed. ${ }^{\text {.1 }}$

Even if Carvel's arrangement fits the definitional characteristics of a tying arrangement, Judge Lumbard, in finding Carvel's arrangement illegal, apparently overlooked the possibility that the economic injuries against which the Northern Pacific test is directed may not result from the variety of tying arrangement employed by Carvel. If this is true, doubts may be raised concerning the rationality of measuring Carvel's alleged tying arrangement under the Northern Pacific test. The usual tie-in attacked under the antitrust laws is thought to involve the sale or lease of two different products or services by one seller who seeks an additional profit from the transaction that he could not obtain absent the tie-in. ${ }^{62}$ Carvel's tie-in seems different, however, since Carvel did not manufacture the tied products, and did not attempt to establish itself in the market for the tied products. ${ }^{53}$ Moreover, if Carvel's tie-in had

51. In Denison Mattress Factory v. Spring Air Co., 308 F.2d 403 (5th Cir. 1962), a franchisee was required to purchase the ingredients of mattresses made under a trademark from sources designated by the franchisor. The court refused to accept the characterization of the practice as a tying arrangement, instead labelling it a requirements contract. $I l d$. at 410. In Anchor Serum Co. v. FTC, 217 F.2d 867 (7th Cir. 1954), the practice attacked involved the right to use the "Anchor" tradename on the condition that the distributors of the hog cholera serum purchase their requirements from Anchor. Id. at 869 . This arrangement was considered a requirements contract, though under the reasoning of the Carvel court it would be a tying arrangement.

52. The concept of a tying arrangement as a monopolizing device, used by a seller to maneuver himself into a second market, is discussed supra at note 23.

53. The court in Carvel and Judge Lumbard in dissent noted that Carvel seemed to make some profit on the sale of cones to the dealers. The court did not think the amount significant enough for concern. Judge Lumbard, on the other hand, was quite concerned with the fact that Carvel paid $\$ 9.50$ per thousand for cones it sold the dealers at $\$ 10.00$. This fact is, however, inadequate to illustrate that Carvel employed the tying arrangement directly as a profit tool. The fifty cent variance represented the overhead involved in Carvel's storage of the cones; it buys the cones in large amounts, in order to kecp a supply on hand to service the dealers' needs. The price variance thus represents an expense by Carvel which presumably would otherwise be charged to the dealers by the suppliers, through a higher cone price to Carvel, had the suppliers carried the risk of storage. Rather than use the tying arrangement as a source of profit, Carvel derives its gain from a royalty on the amount of ice cream mix used by the dealers, and from the sale to the dealers of various non-tied supplies and machinery. See Dealer's Franchiso Agreement, Appendix Brief for Appellee, pp. 85c, 90c, Susser v. Carvel Corp. 332 F.2d 505 (2d Cir. 1964). 
in fact diminished the competition in the market for the end-product elements, a result which is said to be the reason for employing tying arrangements, the ultimate beneficiary of the increased power would not have been Carvel but independent suppliers. It appears unreasonable to assume that Carvel would have sought to increase the market power of its suppliers, since the added power might have given these suppliers the ability to raise the prices on the products sold to Carvel. When seen in this light, Carvel's tie-in does not seem susceptible to characterization as a power-transferring device designed to secure for Carvel a position in the market for the tied products.

With respect to the potential foreclosure of competing suppliers, Judge Iumbard admitted that Carvel's tie-in did not fit the usual pattern, where the seller forecloses all competition in the market for the tied product; as he stated, ". . . it must be conceded that vigorous competition would probably exist among ... suppliers to secure the initial contract with the Carvel organization."Os He nevertheless found the tie-in illegal, arguing that the resulting competition would be substantially different from that which would exist without the tie-in. ". . . [C] ompetition [for the supplier contracts] will most likely take the form of substantial price concessions and the concomitant inability of smaller suppliers effectively to compete with larger producers who are capable of meeting Carvel's price and service demands."55 Although this concept of a "competitive advantage" has been utilized by several lower courts in condemning mergers under section 7 of the Clayton Act," Judge Lumbard's use of it as grounds for decision in a section 3 Clayton Act suit is inappropriate. ${ }^{.7}$ Where the theory has been applied to mergers, the courts have never employed it without a somewhat extensive inquiry into the nature and effect of the com-

54. 332 F.2d 505, 514 (2d Cir. 1964).

55. Ibid. It is not clear whether Judge Lumbard assumed that the larger competitor will always be successful where competing with smaller competitors for contracts. Such an assumption would be unwarranted, for it is quite possible that a smaller competitor could be more efficient or be willing to offer a lower price in hopes of moving into a new market. It must be admitted that Carvel's alleged tying arrangement does not prevent any supplier from ultimately serving the dealers. The arrangement simply channels the suppliers to the dealers through the medium of contracting with Carvel for the system's requirements.

56. See, e.g., Reynolds Metals Co. v. FTC 309 F.2d 223 (D.C. Cir. 1962) ; Procter \& Gamble Co., 3 Trade Reg. Rep. (1964 Trade Cas.) I 16,673 (Dkt. 6901). United States v. Kennecott Copper Corp., 5 Trade Reg. Rep. (1964 Trade Cas.) I 71,181 (S.D.N.Y. 1964). Of interest is the fact that the Kennecott opinion was written by Judge Dawson, who in deciding the Carvel case in the district court did not find any competitive advantage injuries flowing from Carvel's alleged tie-in.

57. In addition to the stated objections to Judge Lumbard's use of such a theory, it is well to note that the theory has been operative only where permanent structural changes in an industry have been created by a merger. A contract setting such as Carvel's one year requirements contracts with suppliers hardly offers a threat of permanent structural change in an industry. The Supreme Court has expressed its greater concern with permanent effects, as opposed to temporary alterations. See Brown Shoe Co. v. United States, 370 U.S. 294 at 332 n.55 (1962) (dicta). 
petitive advantage created by the merger..$^{68}$ Rather than pursue such an inquiry, Judge Lumbard utilized a per se approach and merely assumed that a competitive advantage was created by the Carvel arrangement and that the advantage caused injury in the suppliers' market. It is also possible that the use of this theory in a contract setting, to supply an economic injury where total foreclosure is absent, fails to demonstrate an economic injury significant enough to warrant a per se test of illegality. For whenever parties enter contracts, the buyer's goal is to achieve the best competitive price and the contract will usually be awarded to the most efficient competitor. If Judge Lumbard's theory means that the efficient competitor achieves a competitive advantage and the unsuccessful competitor suffers a compensable injury, then many commonplace commercial contracts would seem to raise an antitrust concern. ${ }^{59}$

Judge Lumbard's dissent also emphasized the dealers' surrender of their right to select suppliers as proof that Carvel's tying arrangement produced a loss of choice by buyers - an injury which the Northern Pacific test sought to prevent. Proof of this injury would seem to require showing that the franchisees were independent businessmen; the fact that they did not receive salaries and did have capital invested in the franchises seems to establish independence. On the other hand, the dealers were not wholly independent, since they were required to follow the elaborate regulations of an operating manual, which governed their behavior in great detail. The franchisees had no choice in the products they could sell; the appearance of their stores was determined by Carvel, as were the uniforms they wore; advertising displays were selected by Carvel; and even the amount of insurance that had to be carried by the franchisees was determined by Carvel. ${ }^{\circ 0}$ Considering these restrictions on the franchisees' independence, their inability to choose sources of supplies does not seem as relevant as in the case of completely independent buyers. In stm, since the alleged tying arrangement did not produce the expected injuries, weight should be given to the possibility that Carvel's arrangement was, in effect, nothing more than a requirements contract.

In addition to the alleged tie-in, the Carvel case also involved the legality of the requirements contract which provided that Carvel would purchase the franchisees' requirements of end product elements from certain suppliers. Although the requirements contract was attacked as an arrangement which precluded the dealers from dealing directly with the suppliers - creating an

58. The kind of test which has been applied to the merger cases thought to involve "competitive advantage (see note 56 sipra) is more comparable to the test of Tampa Electric than to that of Northerm Pacific.

59. This objection to Judge Lumbard's use of the "competitive advantage" theory envisions a large scale contract such as Carvel's. It is not meant to suggest that Judge Lumbard seeks to apply the theory to contracts of unnoticeable proportions.

60. For a more detailed enumeration of the limitations on the dealers' commercial behavior, see Susser v. Carvel Corp., 332 F.2d 505 at 508-09 (2d Cir. 1964), and the Dealer's Franchise Agreement in the Appendix Brief for Appellec, p. 85c, Ibid. 
injury to the dealers rather than to competing suppliers - the presence of a requirements contract in the Carvel system offers an opportunity to compare such contracts to tie-ins.

Requirements contracts have been recognized by the Supreme Court to have potential valid economic purposes and, perhaps for this reason alone, to be deserving of an antitrust test different from tying arrangements. ${ }^{01}$ Among the possible reasons for entering a requirements contract is that such contracts enable the buyer to acquire a guaranteed source of supply for his needs, frequently on favorable price and service terms. Since a requirements contract may involve a one-shot negotiation, it would seem as well that the administrative expenses of entering frequent contracts are avoided. The Supreme Court's relatively lenient attitude towards requirements contracts also seems to imply that such arrangements do not involve an exercise of leverage by the seller or coercion of the buyer - evils often associated with tying arrangements. ${ }^{62}$ This assumption may be unwarranted, however, since it is quite possible that a requirements contract seller may enjoy dominance in the market for the desired product. In such cases the seller might have adequate market power to force a buyer to purchase only his total requirements from the seller, with the harsh alternative of purchasing none at all. ${ }^{.3}$ Thus, in some circumstances, one party to the contract may be able to exert leverage over the other party. Any requirements contract, moreover, will always result in complete foreclosure of competing sellers for the duration of the contract. Finally, in the situation where a buyer would prefer to contract for less than full requirements, a seller who demands a full requirements provision forces the buyer to forego his choice of other suppliers for the volume of products not actually desired. It would appear, on this analysis, that a requirements contract between parties of unequal economic power can yield the precise economic injuries which are said to flow from tying arrangements.

Even so, some may argue that requirements contracts are still to be considered a less evil form of economic practice than tying arrangements because they do not involve a transfer of power from one product to another. This argument, no doubt, would rest on the belief that for a transfer of power to occur, the practice must involve two different products. An example will suffice to illustrate the conceptual difficulty of determining when products do in fact differ. Assume that a retail liquor dealer wishes to stock J.\&B. Scotch whiskey for his many customers who desire that brand. Assume further that the J.\&B. distributor requires the dealer to purchase J.\&B. for his entire requirements of Scotch whiskey in order to get any J.\&B. Then posit the dealer attacking the distributor's practice as a tying arrangement in an anti-

61. See text at notes 23-38 supra.

62. Standard Oil Co. of Calif. v. United States, 337 U.S. 293, 306-07 (1949).

63. In an inverse situation it is also possible that a buyer vith large needs would approach a comparatively smaller seller and demand that the seller provide the buyer's total requirements or suffer the alternative of providing none of the buyer's needs. 
trust action. ${ }^{64}$ The distributor responds in defense that he simply was operating on a requirements contract basis, and demands the case be heard under the test of Tampa Electric, which would enable him to show that the foreclosure he created was at best minimal in the market for whiskey and that valid business purposes justified the practice. The distributor relies upon the theory that even if he has caused the feared injuries of the Northern Pacific case he is selling one product only, rather than tying different products together. The plaintiff, however, argues that the Northern Pacific test governs on the theory that although J.\&B. whiskey appears to constitute a single product, the quantity desired and that which he was forced to purchase arc in fact different products: all the liquor beyond that desired is a different product to the buyer because he did not want it. At this point, the judge henring the case should recognize the similarity between plaintiff's argument on the nature of different products and the theory of tie-in law that the buyer is forced to take a product he does not want in order to acquire a product he wishes to purchase. Whether this example involves a tie-in or a requirements contract thus becomes a problem in the metaphysics of "different" products. As the hypothetical suggests, many requirements contracts can be analyzed as tic-ins both on a definitional level and in terms of the economic injuries resulting from their use. Yet the choice of characterization will be of immense importance to the litigants, since it will likely determine which of two fundamentally different legal tests will be applied to the case.

The third form of exclusive dealing which appeared in the Carvel case was an arrangement which created exclusive dealerships: the dealers were allowed to sell only Carvel or Carvel-approved products. The court in Carvd unanimously disposed of the allegation that the exclusive dealerships constituted an antitrust violation. ${ }^{65}$ Since the plaintiffs had stipulated that they were alleging only per se violations of the antitrust laws, and therefore did not introduce any market data concerning the effect of the exclusive dealerships, ${ }^{\text {co }}$ the court held that plaintiffs had failed to satisfy the Tampa Electric test. As additional support for its decision, the court went on to find that Carvel's exclusive dealerships withstood "any attack" on their legality because of the valid economic purpose which brought them into being - protection of the Carvel trademark. ${ }^{17}$

64. If hypotheticals must bear some correlation to the real world, assume the practice is of such proportions as to attract attention.

65. The court in Carvel found that exclusive dealcrships involved "one form" of exclusive dealing, and by inference held that all forms of exclusive dealing except tying arrangements should be tested under the standards of Tampa Electric rather than those of Northern Pacific. 332 F.2d at 516.

66. See note 45 supra.

67. While the Tampa Electric test allows an inquiry into the purpose of an exclusive dealing arrangement, nothing in the Tampa Electric case suggests that valid purposo standing alone will conclusively establish legality. An exclusive dealing practice, regardless of impeccably good purpose, would no doubt be held illegal if it had significant antlcompetitive effects. 
The value of the Carvel trademark, the court reasoned, would be diluted if the dealers were allowed to sell non-Carvel products over which Carvel might not be able to exercise effective quality control. ${ }^{\text {s }}$

Potential valid economic purpose, however, should not blind a court to the economic injuries which an exclusive dealership may produce, nor to the striking similarity of such injuries to those produced by tying arrangements. A dealer bound by an exclusive dealership agreement has no choice as to the products he can sell. Consequently, the suppliers of all other products which the dealer wishes to sell are completely foreclosed from the dealer's market. And in those cases where the dealer wishes to continue selling the "exclusive" product, the grantor of the exclusive dealership has the ultimate power to revoke the dealership if the dealer does not abide by its restrictions. In such cases, the threat of revocation certainly gives the grantor leverage over the dealer, and insures the dealer's loss of choice and the ensuing foreclosure.

While an exclusive dealership may be thought to involve only the protected product, such arrangements are subject to a definitional analysis which may illustrate the possible comparability of exclusive dealerships and tying arrangements. As long as the dealers are not allowed to sell competing products, each sale of the protected product may be at the expense of the competing product which would have been sold but for the restriction on the range of products offered. In such a situation the exclusive dealership can be used as a vehicle for extending the protected product's penetration of the competitive market. Arguably, in a situation where the dealer would prefer to sell both the protected and the competitive products, the forced continuation of sale of the protected product constitutes what may definitionally be a tie-in of the sale of one product to the sale of another. The exclusive dealership requires the dealer to buy and sell more of the protected product than he desires, and to refrain from buying and selling competitive products. As with requirements contracts, it can be argued that the dealer is buying different products - those he wants and those he doesn't want. ${ }^{60}$ Although this analysis may appear strained, it suggests that exclusive dealerships, as well as requirements contracts, may not only embody the feared injuries of tying arrangements, but may actually involve the definitional equivalent of a tie-in, rendered successful by virtue of the dominant party's leverage.70

The foregoing analysis indicates that it may be difficult for courts to distinguish various forms of exclusive dealing by looking to definitional characteristics and to the economic injuries resulting from a particular practice. For this reason, and because the parties' characterization of the challenged practices will be unreliable, courts will be forced to rely on other grounds of dis-

68. 332 F.2d at 516-17.

69. See text at notes 63-65 sipra.

70. Exclusive dealerships, like requirements contracts, also may have valid business purposes. See Bok, supra note 25, at 307-10. The Uniforas Cousarerctal Code § 2-306(2) codifies one of the economic purposes of exclusive dealerships. 
tinction between the practices if the conflicting tests are to be maintained and applied in a rational manner.

A court might try to distinguish exclusive dealing practices by applying the more lenient test of Tampa Electric to those which involve economies created by vertical integration, leaving other practices to be tested by the Northorn Pacific rule. This, however, would not seem a trustworthy distinction for preserving the dichotomy between the current tests; since exclusive dealing arrangements involve parties at two levels - buyers and sellers - arguably all such arrangements are vertical integrating devices. In the Carvel case, for example, all three forms of exclusive dealing may have functioned as vertical integrating devices. The suppliers, through the requirements contract, constituted what was in effect a manufacturing division; the exclusive dealerships provided a sales division; and the alleged tie-in connected the mantufacturing and sales functions.

Another line of distinction open to courts would involve an inquiry into the reasons for employing any challenged exclusive dealing arrangement. For such an inquiry to yield a rational answer, it would have to rest on facts rather than presumptions. Although the Supreme Court has long adhered to a presumption that tying arrangements have hardly any purpose beyond the suppression of competition, and no redeeming virtues, ${ }^{71}$ the Court also has suggested that tie-ins may be justifiable in two instances - where a small company is trying to gain entry into a new market ${ }^{72}$ and where specifications for the tied products cannot practicably be given. ${ }^{73}$ Given these exceptions, there scems to be no basis for the Court to foreclose the inquiry into purpose when other justifications are offered. The possibility that some tying arrangements may have valid business purposes has been suggested by Professor Bowman. ${ }^{74}$ In addition to the examples he offers, there is also a variety of tying arrangement which involves the sale of a machine, with materials used by the machine tied to the sale, but in circumstances where the seller binds himself to provide the buyer's needs for the materials at market prices. This kind of tie-in may simply be a requirements contract between a seller who makes a market in

71. See, e.g., Northern Pac. Ry. v. United States, 356 U.S. 1, 5 (1958); TimesPicayune Publishing Co. v. United States, 345 U.S. 594, 605 (1953).

72. See Brown Shoe Co. v. United States, 370 U.S. 294, 330 (1962); White Motor Co. v. United States, 372 U.S. 253, 263 (1963); United States v. Jerrold Electronics Corp., 187 F. Supp. 545 (E.D. Pa. 1960), aff'd per curiam, 365 U.S. 567 (1961).

73. The Supreme Court stated in Standard Oil Co. of Calif. v. United States, 337 U.S. 293 (1949): "The only situation, indeed, in which the protection of good will may necessitate the use of tying clauses is where specifications for a substitute would be so detailed that they could not practicably be supplied." 337 U.S. at 306. See Dehydratiny Process Co. v. A.O. Smith Corp., 292 F.2d 653 (1st Cir.), cert. denied, 368 U.S. 931 (1961). See generally Comment, Tying Arrangements Under the Autitrust Law: "The Intcgrity of Product" Defense, 62 Mrch. L. Rev. 1413 (1964).

74. See Bowman, supra note 23. For an explanation of the tying arrangement involved in United States v. Loew's, Inc., 371 U.S. 38 (1962) see Stigler, United Slates v. Loew's Inc.: A Note on Block-Booking, 1963 SUPREME CT. Rev. 152. 
the tied products and a buyer who needs the tied products - an arrangement presumably resulting in the efficiencies associated with requirements contracts. ${ }^{70}$ A presumption that such a tying arrangement has no valid business purpose would be wholly inconsistent with the Supreme Court's analysis of requirements contracts. And, as illustrated by the Carvel case, a tying arrangement may be employed by a trademark franchisor in order to achieve efficient quality control over his franchisees. If, for example, the franchisees used a large number of suppliers, the cost of policing the quality of the product would be greater than where Carvel can pursue quality control over a smaller number of suppliers. ${ }^{76}$

If, however, a court were to pursue an inquiry into the purpose of an exclusive dealing arrangement in order to discover which of the current tests should apply, the Nortiern Pacific test would be sterilized, since the court would have to allow the defendant to enter detailed evidence which could not be ignored through reliance on a sweeping presumption. Notwithstanding this result of an inquiry into purpose, it is doubtful that such an investigation would offer grounds for distinguishing various practices. For unless a court could find that the purposes were "good" or "bad," it would have no basis upon which selection could be made between the conflicting tests. The result of the inquiry would, more often than not, indicate merely that the purpose lay somewhere between the absolutes, and could not by itself be determinative.

In sum, neither the definitional characteristics of a practice, nor the potential economic injuries, nor the purpose for its use, standing alone or in conjunction,

75. This may have been the variety of tie-in before the Supreme Court in International Salt Co. v. United States, 332 U.S. 392 (1947). The tie-in there provided that the seller would fulfill the buyer's needs for the tied products at market prices; if the seller could not so provide, the buyer was frce to shop the market. Id. at 394-95 \& n.5.

76. Beyond the desire to attain efficient quality control. a franchisor is required to maintain some degree of control to protect his trademark Congress established the necessity for some quality controls to protect trademarks in the Lanham Act:

Where a registered mark . . . is . . . used legitimately by related companies, such use shall inure to the benefit of the registrant ... and such use shall not affect the validity of such mark ... provided such mark is not used in such manner as to deceive the public.

60 Stat 429 (1946), 15 U.S.C. \& 1055 (1958). A related company is: "[A]ny person who legitimately controls or is controlled ... in respect to the nature and quality of the goods or services in connection with which the mark is used." 60 Stat. 443 (1946), 15 U.S.C. § 1127 (1958). The consequences to a franchisor who fails to exercise adequate control over his franchisees are severe:

A mark shall be deemed to be "abandoned" . . . when any course of conduct of the registrant ... causes the mark to lose its significance as an indieation of origin. 60 Stat. 444 (1946), 15 U.S.C. $\S 1127$ (1958). See also 60 Stat. 433 (1946), 15 U.S.C. $\S 1064$ (e) (1962).

For an analysis of the quality control aspect of the Carvel case, see Note, $63 \mathrm{Mrrar}$. I. REv. 550 (1965). For an extensive view of trademark franchising and its antitrust implications see Comment, Quality Control and the Antitrust Laus in Tradcmark Licensing, 72 Y ALE L.J. 1171, 1197-98 (1963). 
can offer a reliable basis for distinction which would allow application of the two current tests. With exclusive dealing practices in this posture, maintaining both tests is irrational. It is, of course, possible that the courts might opt to apply the strict test of Northern Pacific to all forms of exclusive dealing. Such an approach, however, seems unwise, since it would result in holding illegal many practices which may have valid economic purposes, may create efficiencies, and may not be anticompetitive. The only reliable alternative open to the courts would require an examination of the purpose and effect of an exclusive dealing arrangement. Whatever the precise formulation of this atternative may be, the result should include the kind of judicial inquiry endorsed by Tampa Electric. ${ }^{77}$ If this approach to the exclusive dealing problem will preserve those arrangements which offer redeeming economic virtues and which do not cause significant anticompetitive effect, the burden of inquiry imposed on the courts is justified.

77. If courts were to opt for the alternative which would remove the per se concept from the area of exclusive dealing, they could take comfort in the fact that other areas of antitrust law may also be moving away from per se standards. See White Motor $\mathrm{Co}_{0}$ v. United States, 372 U.S. 253 (1963), and United States v. Penn-Olin Chem. Co., 378 U.S. 158 (1964), for recent Supreme Court refusals to expand the reach of per se rules. 